\title{
The integration of special needs for people living with disabilities into Tanzania's LIS curriculum
}

\author{
Rebecca Mgunda Majinge ${ }^{1}$ and Vincent Tilubuzya Msonge ${ }^{2}$ \\ rmajinge@gmail.com ORCID: 0000-0002-4645-1232 \\ vtmsonge@gmail.com ORCID: 0000-0002-3617-186X
}

\begin{abstract}
Received: 1 August 2019
\end{abstract}
Accepted: 18 May 2020

\begin{abstract}
This paper presents the findings of a study that examined the integration of special needs into the Library and Information Science (LIS) curriculum by Tanzania's library schools. The social model of disability by Oliver (1990) underpinned the study, which deployed both quantitative and qualitative research approaches in a survey research design. A questionnaire, an interview and content analysis were used in data gathering. The study found that special needs in the LIS programme are integrated at one university as an elective but not covered as a core subject. The study found that the integration of special needs into the LIS curriculum is important in improving library services. Furthermore, it was established in this study that the integration of special needs into the LIS curriculum faced the challenge of relying on library staff who lacked training in special needs in addition to lacking assistive equipment. In addition, inadequate funding, lack of appropriate information resources, and lack of sensitisation and awareness of universities and government decision-makers were other challenges the study identified. The study recommends that courses for meeting special needs are compulsory for undergraduates as well as postgraduates in LIS, but also in disciplines such as engineering and information technology, so that universally accessible buildings that integrate the needs of people with disabilities are built, so that websites suitable for people with disabilities are designed, and so that librarians select and acquire information resources and assistive equipment related to people with disabilities. The government should supply adequate funds to all universities to support people living with special needs.
\end{abstract}

Keywords: Curriculum, hearing impairments, special needs, physical impairments, visual impairments, Tanzania

\section{Introduction}

More than one billion people are living with disabilities worldwide (World Health Organisation 2013: 5). They are marginalised and excluded from participating fully in society (Kitchin 1998: 343, United Nations 2007: 1). In recent years, policies have been adopted by a number of countries with the aim to ensure that the rights of people living with disabilities are promoted, enabling them to participate as equal members of society (International Labour Organisation 2004). In the same spirit, Tanzania has taken initiatives to address how people with disabilities are treated. The National Policy on Disability (United Republic of Tanzania 2004) tackles the challenges of disability including national health initiatives that aim to "eradicate the childhood diseases that cause disablement" (United Republic of Tanzania 2004). Moreover, the Constitution of the United Republic of Tanzania (1998) asserts that "all human beings are equal and are entitled to equal rights irrespective of colour, tribe, gender and region". United Nations Resolution No. 27(a) item (iii) of 20 December 1948 similarly states: "all human beings are born free with equal rights and dignity". This resolution affirms: "It is the right of all human beings to participate in the society hence use its resources for their development and protection. Since a person with a disability is also a human being he/she is equally entitled to these rights" (UN 1948). The International Labour Organisation (2009: 1) states that Tanzania has "implemented a number of laws, policies and standards pertaining to people with disabilities, including their right to productive and good jobs suited to their skills, vocational training and basic services". In 2009, Tanzania ratified the United Nations Convention on the Rights of Persons with Disabilities of 2006. The aim of the convention is "to promote, protect and ensure people living with disabilities enjoy all the human rights such as access to services, health, education, and employment, as well as participation in political issues" (Mpandikizi and Maro 2010: 9).

These policies recognising people living with disabilities notwithstanding, very little initiative is taking place in practice to support this group of people, including in libraries. In Tanzania, for example, most library buildings are inaccessible to people with physical and visual impairments; library materials are not available in the format friendly for people with visual

1. Rebecca M. Majinge is Librarian at the Institute of Finance Management, Dar es Salaam, Tanzania

2. Vincent T. Msonge is Senior Librarian at the Institute Finance Management, Dar es Salaam, Tanzania 
impairments; the assistive equipment provided is not adequate for people with visual, hearing and physical impairments; and librarians are generally not trained to assist people with disabilities. People with disabilities live in our communities and need services in all sectors. All service professions including engineers, information technology (IT) professionals, librarians, bankers and medical doctors need to acquire knowledge related to people with disabilities. For example, engineers should know the requirement of people with disabilities so that they erect universally accessible buildings that integrate the needs of people with disabilities; IT professionals should design websites suitable for people with disabilities; and librarians should select and acquire information resources and assistive equipment relevant to people with disabilities. Mulliken and Djenno (2017) asserted that librarians need to understand what actually works for users with disabilities. Therefore, the integration of special needs of people with disabilities into the Library and Information Science (LIS) curriculum is crucial so that librarians know how to plan for, assist with and acquire information related to people with disabilities.

LIS is a discipline "concerned with the study of the principles and skills required for a systematic collection, organisation and use of society's information resources in libraries" (Ozioko and Nwabueze 2010: 3). "It is also concerned with the forces governing the flow of information resources and provision of ready access to these resources" (Ozioko and Nwabueze 2010: 3). The goal of LIS education is to ensure that qualified librarians are produced (Ezeani, Eke and Ugwu 2015: 4) who are "responsive to the need of the contemporary information environment" (Varalakshmi 2006: 181). The term 'curriculum' refers to "a plan for providing learning opportunities and experiences to the learners to achieve educational goals and specific objectives required by the society" (Shinali, Mnjokava and Thinguri, 2014: 41). The curriculum is found to be fundamental in any education or training programme because "it provides a list of courses or modules offered in the programme as well as information on the content, purpose, method, time/duration, trainers and location" (Ocholla 2001: 2). The intellectual content of the curriculum should change as the demands of the profession change (Edzan, Zainab and Singh 2015: 2). LIS curricula in Africa have shifted from a narrow focus on librarianship to a broader information focus, resulting in the integration into the curricula of courses including those of "knowledge management, information literacy, multimedia, media and publishing studies, records management, IT, and computer technology" (Raju 2015: 170).

LIS programmes in Africa started at the University of Pretoria, South Africa, in 1938. By the 1980s, there were five library schools in Ghana, Nigeria, Senegal and Uganda, and eighteen in South Africa; by 2008, there were about sixty library schools in Africa (Ocholla and Shongwe 2013: 35, Ocholla and Bothma 2007, Okello-Obura and Kigongo-Bukenya 2011).Today, LIS is considered equal to any other academic programme in African countries (Jain and Jorosi 2017). In Tanzania, LIS education began in 1972 at the elementary certificate level under the Tanzania Library Service Board located in Dar es Salaam. The LIS diploma qualification was introduced in 1989 at the School of Library, Archives and Documentation Studies (SLADS) found in Bagamoyo, Pwani region (Mcharazo and Olden 2016, Manda 2006: 2). The University of Dar es Salaam introduced a master's programme in LIS in 1997 and a PhD programme in 2000. Tumaini University Dar es Salaam College (TUDARCo) launched an undergraduate degree programme in LIS in 2003 (Manda 2006: 2). Currently, various universities and colleges in Tanzania run LIS programmes. These are: Moshi Co-operative University, Ruaha University College, Eckenford University of Tanga, Tanzania Public Service College, Jordan University College, Mzumbe University, St. Augustine University of Tanzania (Mtwara campus) and Sokoine University of Agriculture (Burnett 2013). Before the establishment of LIS schools in Tanzania, library professionals were trained overseas - mainly in the United Kingdom, but some in the United States, Australia and Russia (Manda 2006: 2).

As most LIS schools are located in institutions of higher learning, it is easy to ensure that "curriculum development and quality control [are] adequately monitored and evaluated" (Ocholla and Bothma 2007: 56). A curriculum for LIS education usually mirrors the type of skills librarians need to perform their work and meet "the challenges of the dynamic information environment" (Chu 2006: 328). LIS education aims to equip learners with skills necessary for librarians and information professionals to manage and evaluate information efficiently and effectively. In addition, the training prepares them for leadership roles in providing information services, in managing organisational and technological change effectively and in helping diverse information users access and use information for personal, public and organisational decision-making and problem-solving (Morgridge College of Education 2014: 6). LIS schools, particularly in developing countries, have programmes that offer education and training for broader information-related jobs (Ocholla and Bothma 2007, Okello-Obura and Kigongo-Bukenya 2011); however, they come up short when it comes to a curriculum that deals adequately with people living with disabilities.

Alemna (1993: 259) agreed that, in the past, LIS schools in Africa focused on traditional librarianship courses and, as a result, library staff fail to handle the needs of users living with disabilities. Murray (2000: 26) asserted that universities offering LIS courses should strive towards curricula that cater for the needs of users living with visual, hearing and physical impairments. Similarly, newly-trained professionals should be sensitised on understanding the needs of this unique set of users within the relevant information service. Kavulya (2007: 208) emphasised "the need to redefine the role of LIS professionals and design curricula that effectively respond to needs of all categories of users in society".Edzan, Zainab and 
Singh (2015: 2) asserted that "it is important for any programme of study to review its curriculum on [a] continual basis to ensure that the contents remain relevant, of high quality and capable of catering for the demands of the job market".

Overall, LIS educators have the responsibility of preparing future librarians and information professionals to understand and meet the unique information needs of users living with visual, hearing and physical impairments in physical and electronic information environments. Without such relevant training for information professionals, this group of users may end up being discriminated against (Jaeger et al. 2011: 171). Jaeger et al. (2011: 171) contended that future information professionals must be prepared to meet the information needs of users living with visual, hearing and physical impairments and ensure their access to information. Tumuhairwe (2013:2) acknowledged that diversity in LIS education prepares students to design and deliver inclusive services to diverse populations in the information age. In this regard, the integration into the LIS curriculum of content covering needs of such users is essential in its endeavour to offer universal services to users living with visual, hearing and physical impairments. Bonnici, Maatta and Wells (2009: 513) have also called for such inclusion in the LIS curriculum.

\section{Statement of the problem}

Librarians and information professionals should provide universal access to information resources to users regardless of their gender, race, ethnicity, class and abilities. Tumuhairwe (2013:1) contended that librarians in public and private sectors - as custodians of information - are mandated to provide information equitably to diverse library users from different cultural backgrounds, including people living with disabilities. Unfortunately, users living with visual, hearing and physical impairments are under-served and discriminated against because only a few professional librarians understand their information needs and how best to meet them. Librarians often forget that meeting the information needs of users living with disabilities is as important as doing so for other sectors of the population and that nobody should face discrimination (Koulikourdi 2008: 391, United Nations 1948).

Overall, the literature on the integration of special needs into the LIS curriculum in Tanzania has revealed that previous studies in the country have focused on education for people living with disabilities and the challenges facing them. For example, a study by Bangula (2005) investigated the factors influencing academic performance in Tanzania's primary schools. A study by Possi (1999) surveyed the position of children with special needs in education reforms in Tanzania. Emmanuel (2008) examined factors influencing the rate of enrolment of students with visual impairment in the country's integrated secondary schools. Using a case of the visually and hearing impaired in Kinondoni Municipality, Dar es Salaam, Gabriel (2006) carried out a study on disabled people as the group that is overlooked in the struggle to combat the spread of HIV/AIDS. Msuya (2002) examined the information-seeking behaviour of library users in a changing library environment using the case of faculty of law staff members of the University of Dar es Salaam. Kayombo (2010) investigated teachers' competencies in handling pupils with disabilities in Tanzania's primary schools whereas Tungaraza (2010) surveyed the accomplishments and challenges of students with disabilities at the University of Dar es Salaam. There is little research on the extent to which LIS education has integrated the special needs of people living with disabilities.

Koulikourdi (2008), Majinge (2014), Ndumbaro (2009) and Lewis (2013) advocated for a LIS curriculum that takes into account the information needs of users living with disabilities. Lewis (2013: 230) claimed that "individuals with disabilities are hungry for more information and deserve to get it". Despite the importance of providing information services to people living with disabilities, librarians often lack training to cater for this group of users: studies by Lewis (2013), Bodaghi and Zainab (2013) and Rugeyasila (2013) found that LIS professionals lacked relevant training, skills, interest and experience to work with people living with disabilities. Therefore, the aim of this study was to focus on the integration of special needs of users living with visual, hearing and physical impairments into the LIS curriculum in Tanzania.

\section{Objectives of the study}

Specifically, the study sought:

- to examine the education and training of LIS academics and library staff for integration of special needs into the LIS curriculum,

- to determine the readiness of LIS academics to integrate the special needs of users living with visual, hearing and physical impairments into the curriculum,

- to identify challenges for integrating special needs of users living with visual, hearing and physical impairments into the curriculum, and

- to propose/recommend a framework for integration of special needs into the LIS curriculum 


\section{LIS education}

LIS educational programmes in the past "focused mainly on developing physical collections of books and other materials in library buildings staffed by people who know how to select, acquire, organise, retrieve and circulate these materials" (Hollam, Ghosh and Smith 2012). In the 1960s and 1970s, owing to the growing use of computers as a means for accessing and retrieving information, a shift in LIS education occurred with information science being incorporated into the teaching of librarianship (Mehra 2004: 4). Rashidah and Che Norma (2001) cited in Edzan, Zainab and Singh (2015: 8) contended that library schools ought to continue teaching the basics while expanding and upgrading their curriculum to keep in touch with the dynamism of ICTs and the needs of the country and society. Hollam, Ghosh and Smith (2012: 2) maintained that, indeed, these days, "library and information educational programmes extend beyond the physical collections and buildings to the virtual world of the internet". LIS educational programmes today focus on providing information to users who may not necessarily be inside the library building (Hollam, Ghosh and Smith 2012: 2). Malekabadizadeh, Shokraneh and Hosseini (2009: 3) asserted that "LIS education should undergo reform to create and accommodate new interdisciplinary courses and teaching new methods of providing information services". Adeyemi (2017) proffered that the LIS curriculum must adapt its educational activities and services to meet the needs of a modern and dynamic community.

Jaeger et al. (2011: 167) contended that "LIS needs to broaden its scope on diversity to embrace all populations, including the disadvantaged in terms of information access" and that, "in an information age, diversity should embrace the under-represented, the disadvantaged, and the under-served for information professionals to provide inclusive services". Preparing information professionals to provide services that are inclusive of people with visual, hearing and physical impairments begins in LIS schools (Jaeger et al. 2011: 167). Kiomoka (2014: 72) insisted that curricula should be flexible enough to cater for meeting the needs of people living with disabilities. Integrating studies on special needs can empower librarians with the capacity to assist people with disabilities more effectively and efficiently than the traditional library school curricula. Edzan, Zainab and Singh (2015: 8) asserted that the management of LIS schools must be aware of the everchanging demands imposed on the LIS professional. In this regard, "the failure to prepare future librarians to provide inclusive services for diverse populations seems a [great] threat to the long-term viability of libraries as trusted and valued social institutions that facilitate the people's search for the information they need" (Jaeger et al. 2011: 173).

As such, all graduate programmes in LIS should teach about "accessibility issues, assistive technology, and the needs of people with disabilities as users and employees, as well as laws applicable to the rights of people living with disabilities as they affect library services"(Rubin 2002: 4). Libraries themselves ought to provide training opportunities for all library staff and volunteers on issues affecting people living with disabilities in addition to teaching them "effective techniques for providing information services to users with disabilities" (Rubin 2002: 4). Indeed, having a library that is responsive to the diverse needs of the community it serves is a must: "One of the most crucial challenges facing the LIS profession today is to create a workforce that reflects the communities that libraries and information settings serve" (Roy 2001: 214). Librarians, therefore, need skills from LIS schools to equip them to serve all clientele equitably.

In a society of any kind, lack of access to library and information services contributes directly to social exclusion (Ndumbaro 2009: 4). Because of physical limitations, people living with disabilities constitute a disadvantaged group with special needs. Therefore, "how to acquire knowlegde, improve information literacy, and equally participate in social activities amount to a survival and development problem for people living with disabilities" (Wei, Lirong and Chunming 2012: 756). Wei, Lirong and Chunming (2012: 756) claimed that, "as an information dissemination centre, libraries should assume the responsibilities and obligations of providing aids that boost knowledge acquisition for people living with disabilities, so that they can enjoy the right to education through library resources and services". In this regard, equal and universal access is essential. As Riley (2002: 179) explained: "Providing equal universal access to materials and information is one of the fundamental obligations of the LIS profession". Similarly, Heaven (2004: 24) advocates for the provision of "universal access based on egalitarian principles, regardless of one's ability or disability". The ultimate goal is inclusion not exclusion (Heaven 2004).

Irvall and Nielsen (2005) called on library staff to acquire knowledge about various disabilities and how to provide services to users with these disabilities. Yoon and Kim (2012: 151) asserted that "libraries must exist as social facilities that support actively people living with disabilities and help them lead comfortable lives". LIS professionals must take the initiative to make libraries and other settings of information provision more open and welcoming to individuals from underrepresented and under-served segments of the population (Mehra 2004: 7). In addition, libraries should include persons living with disabilities as "participants in the planning, implementation and evaluation of library services, programmes, and facilities" (Rubin 2002). Magara's (2010) study on the challenges to LIS capacity building in Southern Sudan identified that inadequate equipment, inadequate electronic resources, lack of finance for training of librarians and lack of appropriate skills for managing services were challenges library and information services had to contend with in the region. In their study of LIS training in Kenya, Rukwaro and Bii (2015) found that there was a shortage of staff teaching in LIS schools, a 
lack of information resources for teaching and learning, low completion rates and low funding of LIS schools. The existence of these types of challenges affect the provision of services to people living with disabilities to a great extent.

\section{Theory}

There are various models applicable in investigating meeting the information needs of people living with disabilities such as visual, hearing and physical impairments. These include the medical model, charity model and social model of disability. The medical model of disability was developed in 1951 by Parsons (Zajadacz 2015: 192). The model perceives people living with disability as "persons with physical problems directly caused by disease, trauma, or other health condition which need cure or rehabilitation" (Solarsh and Hofman 2006, Harris and Enfield 2003). The focus of the medical model was on medical professionals curing people with disabilities. This approach has limitations because people with disabilities can participate in and contribute to society if the environment created by others allows them to do so (Majinge 2014: 44). The charity model of disability, on the other hand, treats individuals living with disabilities as victims of their impairments who need protection and "special services, special schools, and charitable donations" (Harris and Enfield 2003: 170). This model tends to dwell on "social support mechanisms and benevolence, rather than justice, equality and self-determination" (Arnott 2011).

The social model of disability was developed by Oliver (1990) and builds on the ideas of the United Kingdom's Union of the Physically Impaired Against Segregation, an organisation founded in the mid-1970s. The social model of disability posits that physical, attitudinal or behavioural social barriers may disable people (Robertson 2001). Indeed, "things that impose restrictions on people living with disabilities under this model include individual prejudice, institutional discrimination, inaccessible public buildings, unusable transport systems, segregated education and work arrangements" (Oliver 1996: 33). The focus of the social model of disability is on changing the negative attitude of society towards people living with disabilities and creating an environment that simplifies their lives and facilitates their participation in all aspects of community activities (Majinge 2014:54). This outcome can be achieved under the principle of universal design that envisages measures simplifying life for everyone by making products, communications and a built environment that people, including those with impairments, can use at equal cost (Barnes 1998 in Shava 2008: 17). The model asserts that LIS education should integrate special needs into the curriculum so that inclusive services to special groups of people can be provided. These aspects of the social model of disability are discussed in the context of Tanzania as this paper builds a case for the integration of special needs into the LIS curricula in the country. This model has been adopted based on the notion that the removal of barriers that hinder access to facilities (such as health, education, employment, transport, information and other social services) by people living with disabilities includes the effective integration of special needs of this group of people into Tanzania's LIS curriculum.

\section{Methodology}

The study was conducted in Tanzania's three administrative regions of Dar es Salaam, Morogoro and Pwani. In these regions, five institutions were studied. These were the University of Dar es Salaam (UDSM), Mzumbe University (MU), Sokoine University (SUA), Tuimani University Dar es Salaam College (TUDARco) and the School of Library, Archives and Documentation Studies (SLADS). These participants were chosen primarily because they are involved in the teaching of LIS. The research gathered both quantitative and qualitative data through a questionnaire, interviews and document analysis. People with disabilities still face many challenges, even in an inclusive society, therefore, the inclusion of a qualitative approach was important to represent their voices as it enabled robust information based on experiences to be gathered. Related studies that used mixed methods approaches to investigate people with disabilities are Arefaine (2008), Mbugua, Odini and Chege (2018), Majinge (20014), Seyama (2009) and Ndumbaro (2009). The data gathered through questionnaires were analysed using Microsoft Excel, while the data gathered through interviews and from documents were subjected to thematic analysis.

The study generated data from 113 respondents comprising heads of library services, LIS academic staff, library staff and people living with hearing, physical and visual impairments. Convenience and snowball sampling were used to select respondents. Convenience sampling was used to select academic and library staff. Snowball sampling was used to identify people living with hearing, physical and visual impairments because the researchers were not able to establish the actual disability population of the participating institutions in advance of the study. The response rates for all categories of respondents and individual institutions, as well as totals, can be seen in Table 1. 
Table 1 Response rates from individual institutions $(\mathrm{N}=113)$

\begin{tabular}{lcccc}
\hline Institutions & LIS academic staff & Library staff & $\begin{array}{c}\text { People with } \\
\text { disability }\end{array}$ & $\begin{array}{c}\text { Head of library } \\
\text { services }\end{array}$ \\
\hline UDSM & $14(12.4 \%)$ & $10(8.8 \%)$ & $15(13.2 \%)$ & $1(0.9 \%)$ \\
MU & $5(4.4 \%)$ & $16(14.1 \%)$ & 0 & $1(0.9 \%)$ \\
SUA & $7(6.2 \%)$ & $11(9.7 \%)$ & 0 & $1(0.9 \%)$ \\
TUDARco & $8(7.1 \%)$ & $6(5.3 \%)$ & $1(0.9 \%)$ & $1(0.9 \%)$ \\
SLADS & $8(7.1 \%)$ & $6(5.3 \%)$ & $1(0.9 \%)$ & $1(0.9$ \\
Total & $\mathbf{4 2 ( 3 7 . 2 \% )}$ & $\mathbf{4 9 ( 4 3 . 2 \% )}$ & $\mathbf{1 7}(\mathbf{1 5} \%)$ & $\mathbf{5 ( 4 . 4 \% )}$ \\
\hline
\end{tabular}

\section{Findings and discussion of the results}

This section presents and discusses the results of the study. The results focus on education and training related to services for people with disabilities that is received at LIS schools. They also cover the readiness of LIS academics to integrate needs of users living with visual, hearing and physical impairments into the curriculum; challenges to integrating these needs into the curriculum; and views on their integration into the LIS curriculum.

\subsection{Education and training related to services for people living with disabilities}

Library staff were asked to indicate whether they have had education and training related to services for people living with disabilities. The vast majority $(47 ; 96 \%)$ responded negatively; only two responses $(4.1 \%)$ were in the affirmative. LIS academic staff were asked the same question. Twenty-two (52\%) academic staff responded that they did not have such education and training, whereas twenty (48\%) indicated that they did. Those who said they did have such education and training indicated that it was at the diploma and degree level. It emerged that the Degree of Education at one university had some components relating to people with disabilities. On the other hand, the LIS curricula completed by study participants had not integrated content related to services for people living with disabilities. Responding to the question: Does the programme of your LIS integrate special needs relating to services for people with disabilities? participants reported that the LIS curriculum did not integrate any education on special needs. They were also required to respond to the question: Does your university or college offer LIS education in a certificate, diploma, degree, masters and PhD level? The responses from LIS academic staff included all five levels.

The curriculum documents that were analysed show that, in all institutions surveyed, only one had integrated special needs for people with disability into the curriculum, as an optional subject. Other institutions still taught subjects such as Introduction to Computers and their Applications, Introduction to LIS, Principles Of Information Management, Legal and Ethical Issues in Information Management, Communication Skills, Introduction to Statistics, Cataloguing and Classification, Collection Development, Information Literacy, Desktop Publishing, Abstracting and Indexing, Introduction to Database Management, Principles of Library Automation, Knowledge Management, Marketing of Information Services, Digital Libraries and Institutional Repositories, Research Methodology, and so on. On the other hand, the University of Illinois, for example, taught information services for a diverse population with a course that was designed to prepare future information professionals capable of developing and providing inclusive services to underrepresented populations such as those with disabilities.

Overall, the study confirmed that education on special needs related to services for people living with disabilities was not integrated into the LIS curriculum at any level. This finding aligns with Majinge (2014) who established that there were no trained or experienced staff to assist users with visual impairment and those in wheelchairs because library programmes and the curricula of library schools did not include a component on the special needs of people living with disabilities. A study by Ndumbaro (2009) found that there were only a few members of staff trained to serve people with visual impairments. Similarly, Arefaine (2008) asserted that the provision of special education and other services to people with disabilities remains largely limited.

\subsection{Readiness of LIS academic staff to integrate special needs into the LIS curriculum}

Library staff were asked to indicate whether integration of special needs into the LIS curriculum was important. The majority $(46 ; 94 \%)$ responded positively with only three $(6 \%)$ responding negatively. Those who responded positively indicated that it was important to be responsive to particular needs of and services for people living with disabilities. Moreover, they explained that integration would help library staff receive training on issues relating to people with disabilities and assist them accordingly when it came to using the library and its information resources. Furthermore, they explained that the integration of special needs into the LIS curriculum would help library staff to plan and budget for services relating to people living with disabilities. On the other hand, the respondents who responded negatively indicated that it is not necessary to 
integrate special needs into the LIS curriculum, as library users with disabilities were very few. They also explained that the integration of special needs into the LIS curriculum was expensive in terms of training staff and acquiring assistive equipment and information resources for people living with disabilities.

LIS academic staff were asked whether they were willing to integrate special needs relating to people living with disabilities into the LIS curriculum. All forty-two LIS academic staff responded positively. In addition, they were asked to indicate whether it was important to integrate special needs into the LIS curriculum. Again, the responses were positive among all LIS academic staff. LIS academic staff explained that library personnel need training to assist people living with disabilities effectively and efficiently; that people living with disabilities need information services just like people without disabilities; and that people living with disabilities had for many years been neglected. Trained workers were required to provide universal services to users regardless of their ability or disability.

People living with disabilities were asked whether the integration of special needs into the LIS curriculum would improve services provided by the library to people with disabilities. All of the seventeen respondents in this group answered in the affirmative. In addition, they were asked about why they believed integration of special needs into the LIS curriculum would improve library services. They were unanimous in their response that the library work force would then be trained on issues relating to people living with disabilities and be equipped with skills for handling, assisting, planning for and budgeting for people living with disabilities in terms of information resources, assistive equipment and infrastructure.

Overall, the findings confirmed that the integration of special needs into the LIS curriculum is important because trained workers will consequently be able to improve the provision of universal library services to users, including those with disabilities. Irvall and Nielsen (2005: 8) asserted that library staff should know about varied abilities and how to meet the information needs of all people. Similarly, Majinge (2014: 233) contended that, in the absence of the integration of a component on the special needs of people with disabilities into the curricula at all levels, libraries will not have well-trained and experienced staff capable of assisting people with disabilities. In the same vein, Seyama (2009: 126) recommended that "staff training and awareness-raising programmes be developed to boost library services". Furthermore, Seyama (2009) recommended that "members of staff need to be educated on the abilities and realistic limitations of people with special needs" (126).

\subsection{Challenges to integrating special needs into the LIS curriculum}

Library staff were asked about the challenges they encountered in the provision of library services to people living with disabilities. Forty-seven (96\%) indicated poor infrastructure, forty-five (92\%) cited untrained staff, forty-five (92\%) mentioned information resources, forty-three (88\%) indicated assistive equipment, thirty $(61.2 \%)$ mentioned inadequate funds and three $(6.1 \%)$ cited inadequate readers (persons who read for people with visual impairments) as challenges. Figure 1 shows multiple responses of the library staff from all the institutions surveyed. The heads of library services were also interviewed on the challenges their libraries experienced in providing services to people living with disabilities. The responses show that the challenges were poor infrastructure, lack of trained staff, lack of information resources, lack of library policy, inadequate funds, lack of assistive equipment, and lack of readers.

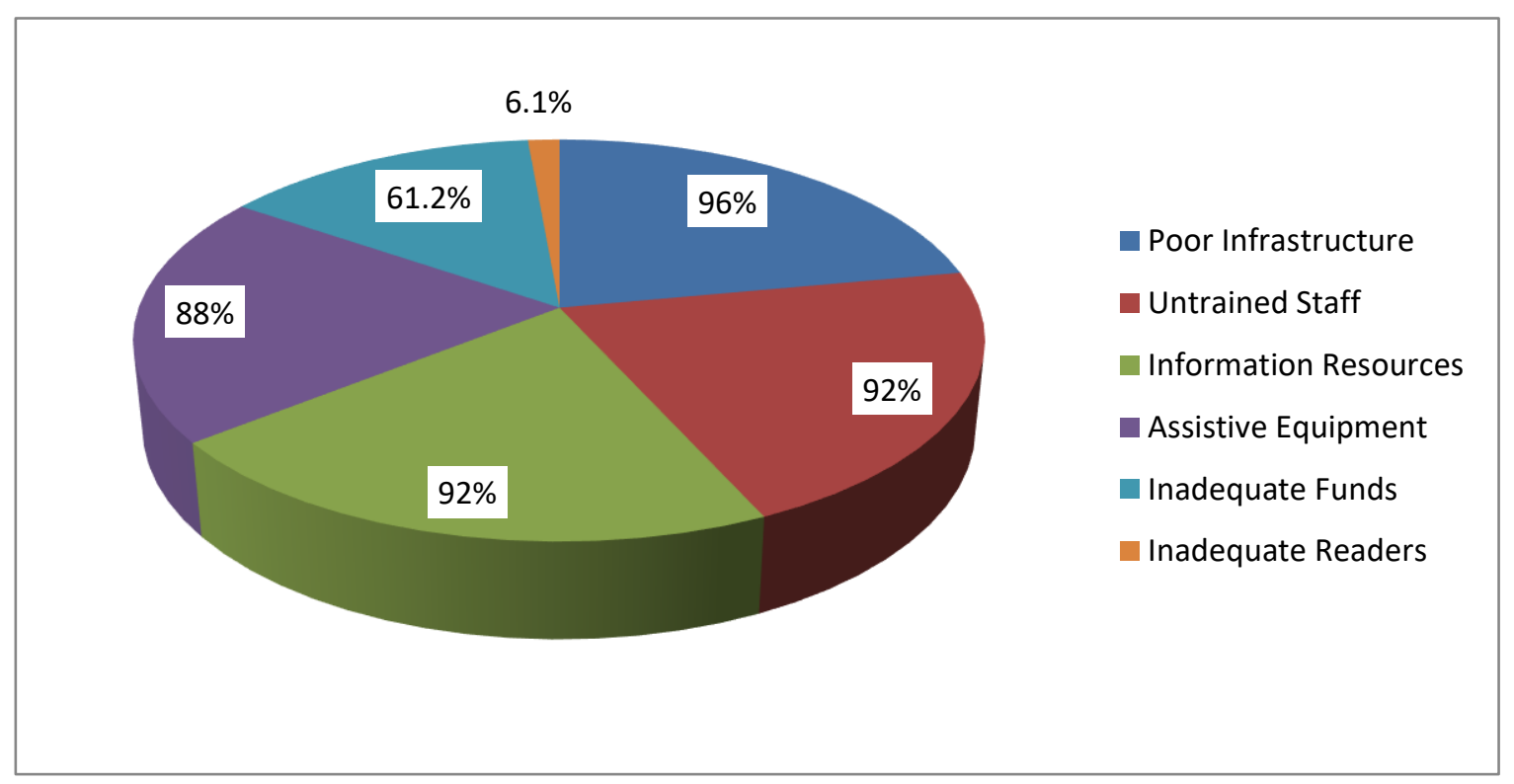

Figure 1 Challenges library staff face in providing library services ( $N=49$ ) 
People living with disabilities provided responses on the challenges they faced in accessing and using library services. They indicated that these were: lack of information resources (Braille materials), lack of assistive equipment, changes in library shelf arrangements, lack of trained staff, inadequate library readers, user-unfriendly library infrastructure and negative attitude of staff. One of the students living with visual impairments complained:

\section{Some lecturers are still negative with students living with visual impairments. You hear that this is the picture. I cannot see, how can I know?}

Furthermore, LIS academic staff were interviewed on the challenges that hindered the integration of special needs relating to people living with disabilities into the LIS curriculum. They identified the following challenges: lack of trained staff, lack of assistive equipment, lack of information resources (Braille materials), inadequate funding, and unwillingness of decision-makers to enrol students living with disabilities. In this regard, one of academic staff claimed:

The decision-makers in some LIS schools do not want to enrol students living with disabilities for fear that they do not have manpower to train them; there is no teaching and learning information resource (Braille) for the students living with visual impairments to use. Moreover, they fear that they do not have assistive equipment and their infrastructure was not friendly to people living with disabilities. However, they forget that people living with disabilities are human beings and need to be trained and learn just like other people without disabilities.

\subsection{Integration of special needs into the LIS curriculum}

Library staff were asked to comment on the integration of special needs into the LIS curriculum. Comments were varied with thirty-five $(71.4 \%)$ recommending that special needs be integrated into the LIS curriculum to build library capacity, four $(8.1 \%)$ saying that universities should provide enough budget for the library to improve services to people with disabilities, and three $(6.1 \%)$ mentioning that trained staff with special needs should be employed. Another two (4\%) suggested that the government formulate a policy on people with disabilities, whereas two (4\%) said that library services should be improved, and another two (4\%) called for the provision of training on the use of assistive equipment. One mentioned boosting sensitisation and awareness; one said that infrastructure should be friendly to people with disabilities; and one said that the LIS curriculum should indicate how to handle and assist people with disabilities. Table 2 presents these responses.

Table 2 Comments on the integration of special needs into the LIS curriculum: library staff responses ( $\mathrm{N}=49$ )

\begin{tabular}{lcc}
\hline Responses & Frequency & Percentage \\
\hline Special needs should be integrated in the LIS curriculum to build capacity & 35 & $71.4 \%$ \\
$\begin{array}{l}\text { Universities to provide enough budget for the library to improve services } \\
\text { to people with disabilities }\end{array}$ & 4 & $8.1 \%$ \\
Trained staff with special needs should be employed & 3 & $6.1 \%$ \\
Government should formulate policy with regard to people with disabilities & 2 & $4 \%$ \\
Implement disability services in libraries & 2 & $4 \%$ \\
Training on the use of assistive equipment & 2 & $4 \%$ \\
Sensitization and awareness should be encouraged & 1 & $2 \%$ \\
Infrastructure should be friendly to people with disabilities & 1 & $2 \%$ \\
LIS curriculum should indicate how to handle and assist people with & 1 & $2 \%$ \\
disabilities & &
\end{tabular}

LIS academic staff were also asked to comment on the integration of special needs into the LIS curriculum. Their responses highlighted the following requirements: taking into account the needs of people with disabilities, providing sensitisation and awareness among staff responsible for curriculum development, and establishing a policy aimed to integrate special needs into the curriculum of all disciplines at undergraduate as well as postgraduate level. As people with disabilities have their inalienable rights pertaining to accessing information, they need such access in all sectors such as banks, hospitals and insurance. In addition, LIS academic staff recommended building user-friendly infrastructure, the training of staff themselves responsible for training, and acquiring information resources and assistive equipment. Furthermore, they recommended that the government provide enough funds to universities for them to afford the expensive 
information resources and equipment for use by people with disabilities. Old buildings should be modified to facilitate access to people living with disabilities which are visual and physical.

A similar question was posed to the heads of library services. They indicated that enough funds are needed to enrol staff for long and short-term courses on special needs. Moreover, decision-makers should budget for people with disabilities to improve library services, acquire information resources and assistive equipment, and provide services to people living with disabilities. In addition, they recommended that the LIS curriculum be reviewed to integrate special needs. Furthermore, they called for thorough research to investigate the best way to integrate special needs modules into the LIS curriculum. People with disabilities were also asked to comment on the integration of special needs into the LIS curriculum. Their responses highlighted the following requirements: special needs be integrated into the LIS curriculum to have trained staff capable of planning and assisting people with disabilities in libraries; the construction of user-friendly buildings that could accommodate the needs of people with disabilities; the acquisition of assistive equipment and information resources suitable for people with visual impairments; and education to be inclusive of people with disabilities. In short, all the categories of respondents affirmed the need to improve library services by extending them to people with disabilities, not only by integrating their special needs into the LIS curriculum, but also by providing supportive environments.

\section{Conclusion and recommendation}

This paper has discussed the integration of special needs for people living with disabilities into the LIS curriculum by Tanzania's library schools. The findings revealed that library staff generally lack training in special needs relating to people with disabilities. Moreover, most of the LIS academic staff were not trained in catering for special needs. On the other hand, the findings show that LIS academic staff were ready to integrate special needs into the LIS curriculum, explaining that the integration of special needs was vital to the training of LIS professionals and would allow them to assist people with disabilities and, at the same time, improve library services. The study also found that the integration of special needs into the LIS curriculum had to contend with not only the lack of staff trained in special needs, but also a lack of assistive equipment, inadequate funding, lack of information resources (Braille materials) and a lack of sensitisation and awareness among university and government decision-makers. Against this backdrop, the study recommends that staff be exposed to special needs training related to people with disabilities and that government provide enough funds and formulate policy related to people with disabilities. Moreover, it should be madatory for the physical layout of the buildings in all universities to be made accessible . Library programmes and, in fact, the curricula of all programmes at all levels should include special needs for people with disabilities. Based on Oliver's (1990) social model of disability, the integration of special needs into the LIS curriculum is important to ensure that library staff are trained and empowered to assist, plan and budget for people living with disabilities and, thus, provide universal library services to users regardless of visual, hearing and physical impairments

\section{References}

Adeyemi, J.A. 2017. Trends and issues in library and information science curriculum in Nigeria. Academia Journal of Educational Research, 5(10): 306-313.

Alemna, A. 1993. Library provision for the blind in Africa. [Online]. http://forge.fh-potsdam.de/ IFLA/INSPEL/93-4alan.pdf (29 July 2013).

Arefaine,Y.G. 2008. Policy and provision for students with disabilities in higher education: the Ethiopian case. MA thesis. University of Oslo.

Arnott, G. 2011. The disability support worker. French Forest, NSW: Pearson.

Bangula, A. R. 2005. Factors influencing academic performance of students with visual impairment in primary schools in Tanzania. MA thesis. University of Dar es Salaam.

Bodaghi, N. B. and Zainab, A. 2013. Examining the accessibility and facility for the disabled in public and university library buildings in Iran. Information Development, 29(3): 1-10.

Bonnici, L.J., Maatta, S.L., and Wells, M.K. 2009. US national accessibility survey: librarians serving patrons with disabilities. New Library World, 110(11/12): 512-528.

Burnett, P. 2013. Challenges and problems of library and information science education in selected African countries. Paper presented at the 79th IFLA General Conference and Assembly. 17-23 August 2013. Singapore.

Chu, H. 2006. Curriculum of LIS programs in the USA: a content analysis. Proceedings of the Asia-Pacific Conference on Library and Information Education and Practice (A-LIEP 2006). C. Khoo, D. Singh and A.S. Chaudhry, Eds.. 3-6 April 2006. Singapore: School of Communication and Information. 328-337.

Edzan, N.N., Zainab, A.N. and Singh, D. 2007. Producing library professionals: the MLIS programme. Paper presented at the International Conference on Libraries (ICOL 2007). 31 October-2 November 2007. Penang, Malaysia.

Emmanuel, F. 2008. Factors influencing enrolment rate of students with visual impairment in the integrated secondary schools in Tanzania. MA thesis. University of Dar es Salaam.

Ezeani, C.N., Eke, H.N. and Ugwu, F. 2015. Professionalism in library and information science: an examination of current trends, needs and opportunities in academic libraries in Southeast Nigeria. The Electronic Library, 33(1): 2-18. 
Gabriel, I. 2006. Disabled people: the forgotten group in the struggle to combat the spread of HIV/AIDS: the case of visually and hearing impaired people in Kinondoni Municipality. MA thesis. University of Dar es Salaam.

Harris, A. \& Enfield, S. 2003. Disability, equality, and human rights: a training manual for development and humanitarian organizations. Oxford: Oxfam GB.

Heaven, S. 2004. The provision made by higher education library services for people with disabilities. Library and Information Research, 28(90): 24-30.

Hollam, G., Ghosh, S.B. and Smith, K. 2012. Guidelines for professional Library/Information Education Programs. [Online]. https://www.ifla.org/files/assets/set/publications/guidelines/guidelines-for-professional-library-informationeducational-programs.pdf.

International Labour Organisation (ILO). 2004. Employment of people with disabilities : the impact of legislation (East Africa) : United Republic of Tanzania country profile. Geneva: ILO. [Online]. https://www.ilo.org/wcmsp5/groups/public/---ed_emp/---ifp_skills/documents/publication/wcms_107844.pdf.

International Labour Organisation (ILO). 2009. Inclusion of people with disabilities in the United Republic of Tanzania (Fact sheet). Addis Ababa: ILO, Skills and Employment Department.

Irvall , B. and Nielsen, G.S. 2005. Access to libraries for persons with disabilities - checklist. The Hague: IFLA.

Jaeger, P.T., Subramaniam, M.M., Jones, C.B. and Bertot, J.C. 2011. Diversity and LIS education: inclusion and the age of information. Journal of Education for Library and Information Science, 52(2): 166-183.

Jain, P. and Jorosi, B.N. 2017. LIS Education at University of Botswana: evolution, opportunities and challenges. DESIDOC Journal of Library \& Information Technology, 37(1): 42-50.

Kavulya, J.M. 2007. Training of library and information science (LIS) professionals in Kenya. Library Review, 56(3), 208223.

Kayombo, B. 2010. Teacher's competency in handling pupils with disabilities in inclusive primary school in Tanzania. MA thesis. University of Dar es Salaam.

Kiomoka, D.J. 2014. Children with visual impairments in Tanzania: an investigation of the challenges which children with visual impairments face in learning and participation in inclusive primary schools. MA thesis. Hedmark University.

Kitchin, R. 1998. Out of place, knowing one's place, space, power and the exclusion of disabled people. Disability \& Society, 13(3): 343-356. DOI:10.1080/09687599826678.

Koulikourdi, A. 2008. Library education and disability issues. Education for Information, 26: $203-212$.

Lewis, J. 2013. Information equality for individuals with disabilities: Does it exist? The Library Quarterly, 83(3): 229-235.

Magara, E. 2010. Challenges of Library and Information Science capacity building in Southern Sudan: a situational analysis. Paper presented at the 2010 IST-Africa Conference Proceedings. 19-21 May 2010. Durban, South Africa [Online]. https://ieeexplore.ieee.org/document/5753004 (27 March 2015).

Majinge, R.M. 2014. Library services provision for people with visual impairment and in wheelchairs in academic libraries in Tanzania. PhD thesis. University of KwaZulu-Natal.

Malekabadizadeh, F., Shokraneh, F. and Hosseini, A. 2009. The role of Library and Information Science education in national development. Library Philosophy and Practice (e-journal): 259.

Manda, P.A. 2006. State of ICTs in LIS curriculum in Tanzania. Regional workshop on Integrating ICTs in Library and Information Science curriculum in Africa. Windhoek, Namibia. 21-23 November.

Mbugua, E.N., Odini, C. and Chege, A. 2018. Provision of information services to the visually impaired students at Thika School for the Blind. International Journal of Humanities and Social Science, 8(8): 46-56.

Mcharazo, A.A.S and Olden, A. 2016. Fifty years of Tanzania's national/public library service. Alexandria: The Journal of National and International Library and Information Issues, 1-9.

Mehra, B. 2004. Serving learning in library and information Science (LIS) Education: connecting research and practice to community. UCLA Journal of Education and Information Studies, 1(1): 1-27.

Morgridge College of Education. 2014. Library and Information Science student handbook 2014-2015. Denver: University of Denver. [Online]. http://morgridge.du.edu/wp-content/uploads/2014/09/LIS-handbook-2014-2015.pdf_(22 January 2015).

Mpandikizi, G and. Maro, R. 2010. Tanzania Human Rights Report 2009. Dar es Salaam: Legal and Human Rights Centre.

Msuya, J. 2002. Information seeking behaviour of library users in a changing library environment: the case of faculty of law staff members, University of Dar es Salaam. University of Dar es Salaam Library Journal, 4(1/2): 58-74.

Mulliken, A. and Djenno .M. 2017. Faculty visions for teaching web accessibility within LIS Curricula in the United States: a qualitative study. The Library Quarterly, 87(1): 36-54.

Murray, J. 2000. The training needs of school library staff for service delivery to disabled students. School Libraries Worldwide, 6(2): 21-29.

Ndumbaro, R. 2009. Library and information services provision for people with visual impairment in selected university and public libraries in Tanzania. MA thesis. University of Dar es Salaam.

Ocholla, D.N. and Bothma, T. 2007. Trends, challenges and opportunities for LIS education and training in Eastern and Southern Africa. New Library World, 108(1/2): 55-78.

Ocholla, D.N. 2001.Review and revision of Library and Information Science curriculum in a South African university and the usage of follow- up study and advertisement scanning methods. Proceedings of the Annual Conference of CAIS. DOI:10.29173/cais22. 
Ocholla, D. and Shongwe, M. 2013.An analysis of the Library and Information Science (LIS) job market in South Africa. South African Journal of Library and Information Science, 79(1): 35-43.

Okello-Obura, C. and Kigongo-Bukenya, I.M.N. 2011. Library and information science education and training in Uganda: trends, challenges and the way forward. Makerere: Education Research International. DOI:10.1155/2011/705372.

Oliver, M. 1990. The politics of disablement: a sociological approach. New York: St. Martin's Press.

Oliver, M. 1996. Understanding disability from theory to practice. London: Macmillan Press.

Ozioko, R.E. and Nwabueze, A.U. 2010. Justification for reform in Library and Information Science education in Nigerian universities. Library Philosophy and Practice (e-journal). 397. [Online]. https://digitalcommons.unl.edu/libphilprac/397 (9 April 2015).

Possi, M.K. 1999. The place of special children in education reforms in Tanzania: a critique. Papers in Education and Development, 20: 1-17.

Raju, J. 2015. LIS education in the digital age for an African agenda. Library Trends, 64(1): 161-177.

Riley, C.A. 2002. Libraries, aggregator databases, screen readers and clients with disabilities. Library Hi Tech, 20(2): $179-187$.

Robertson, L. 2001. Access for library users with disabilities. London: Society of College, National and University Libraries.

Roy, L. 2001. Diversity in the classroom: incorporating service-learning experiences in the library and information science curriculum. Journal of Library Administration, 33(3/4): 213-228.

Rubin, R.J. 2002. Serving people with disabilities: different voices, common quest. Chicago: Association of Specialized and Cooperative Library Agencies.

Rugeyasila, A.A. 2013. Information needs and seeking behavior of pupils with visual impairments of Uhuru Mchanganyiko primary school in Dar es salaam, Tanzania. MA thesis. University of Dar es Salaam.

Rukwaro, M.W and Bii, H. 2015. Library and information science (LIS) education and training in Kenya: emergence, evolution, challenges and opportunities. International Journal of Library and Information Science, 8(2): 11-18.

Seyama, L.G. 2009. Information seeking behaviour of students with visual impairments: a case study of the KwaZuluNatal. MA thesis. University of KwaZulu-Natal.

Shava, K. 2008. How and in what ways can western models of disability inform and promote the empowerment of disabled people and their participation in mainstream Zimbabwean society? MA thesis. University of Leeds.

Shinali, M.C., Mnjokava, C. and Thinguri, R. 2014. Adaptation of the curriculum to suit children with visual impairment in integrated ECD centres in Kenya: a case of Narok sub-county. Educational Research International, 3(4): 40-45.

Solarsh, G. and Hofman, K. J. 2006. Developmental disabilities In Disease Mortality in Sub-Saharan Africa. 2nd ed. D.T. Jamison et al. Eds. Washington, DC: The World Bank. 145-148.

Tumuhairwe, G.K. 2013. Analysis of Library and Information Science/Studies (LIS) education today: the inclusion of indigenous knowledge and multicultural issues in LIS curriculum. Singapore: IFLA WLIC.

Tungaraza, F.D. 2010. Accomplishments and challenges facing students with disabilities at the University of Dar es Salaam: thirty years of navigating the hill. Papers in Education and Development, 29: 134-155.

United Nations .1948. United Nations Universal Declaration of Human Rights. Geneva: United Nations. [Online]. http://watchlist.org/wordpress/wp-content/uploads/Universal-declaration-of-human-rights.pdf (5 January 2015)

United Nations. 2007. From exclusion to equity: realizing the rights of persons with disabilities. Geneva: United Nations. [Online]. https://www.un.org/esa/socdev/enable/documents/ipuhb.pdf (30 April 2016).

United Republic of Tanzania. 1998. The Constitution, 1977. Dar es Salaam: Parliament of the United Republic of Tanzania.

United Republic of Tanzania. 2004. National Policy on Disability. Dar es Salaam: Ministry of Labour, Youth and Development and Sports.

Varalakshmi, R.S.R. 2006. Educating 21st century LIS professionals' needs and expectations: a survey of Indian LIS professionals and Alumni. Journal of Education for Library and Information Science, 47(3): 181-199.

Wei, Z., Lirong, S. and Chunming, L. 2012. An analysis of the development of China digital library for visual impairment website. The Electronic Library, 30(6): 756-763.

World Health Organization. 2013. Disability: report by secretariat. [Online]. http://apps.who.int/iris/bitstream/10665/78621/1/B132_10-en.pdf (24 March 2016).

Yoon, H. and Kim, S. 2012. On the improvement of the copyright law of Korea for library services for persons with disabilities. Journal of Librarianship and Information Science, 45(2): 140-152.

Zajadacz, A. 2015. Evolution of models of disability as a basis for further policy changes in accessible tourism, Journal of Tourism Futures, 1(3): 189-20. DOI:10.1108/JTF-04-2015-0015. 